\title{
New Evidence on \\ Ownership Structures in Germany
}

F. Jens Köke

ZEW Discussion Paper No. 99-60

October 1999

\begin{abstract}
Ownership structures are an important element of the theory explaining corporate governance. This study presents detailed descriptive evidence on the ownership structures of German manufacturing firms. It addresses several shortcomings of the previous German empirical literature: First, we study all legal forms of a Kapitalgesellschaft, firms that generally have a separation of ownership and control. We do not focus exclusively on the listed $A k$ tiengesellschaft (AG) but include many non-listed firms. Second, we examine changes in the ownership structure. This is a new and important approach because these changes are frequently related to corporate performance. Third, we analyze the higher levels of ownership structures, i.e. ownership structures of the direct owners. Thereby we address an issue quantitatively which only recently became subject of empirical studies. Finally, we find that crossownership is of minor relevance in the German manufacturing sector. However, our measure of cross-ownership represents only a lower bound.
\end{abstract}

Key Words: ownership structure; corporate governance

JEL Classification: G32

Financial support was given by Deutsche Forschungsgemeinschaft (DFG) (grant no. BO 934, 71). This support and valuable comments from Axel Börsch-Supan, Silke Januszewski and Joachim Winter are gratefully $\mathfrak{x}$ knowledged. Dominik Krupp and Ingo Sänger provided helpful research as sistance.

Address for correspondence:

Jens Köke

Centre for European Economic Research

Phone: 0049-621-1235-190

P.O. Box 103443

Fax: 0049-621-1235-223

68034 Mannheim, Germany.

E-mail: koeke@zew.de 


\section{Non-Technical Summary}

Corporate ownership structures around the world are very diverse but there seem to be two distinct groups. In the Anglo-Saxon countries the majority of shares is widely held, whereas in continental Europe shares tend to be concentrated in the hands of a few large shareholders. For Germany, empirical studies report large share blocks and cross-ownership of firms. Furthermore, it is often assumed that ownership structures in Germany do not change much over time.

Ownership structure is one important element of the complex system of corporate governance - the legal and institutional framework by which enterprises are governed. Economic theory suggests that managers of large corporations will not maximize shareholder value, i.e. act in the best interest of the shareholders, if they are not controlled by a small number of shareholders. But also the type of shareholder can influence management behavior: agency costs resulting from a divergence of ownership and control should be relatively small if individuals are the shareholders because corporate shareholders like other non-financial firms have internal agency conflicts.

This study documents the ownership structure of large German manufacturing firms for the years 1994-1998 and identifies potential sources of agency costs. It includes a large number of firms which possibly can have agency costs, i.e. listed and non-listed firms as well as firms in the legal form of the $\mathrm{AG}$ and $\mathrm{GmbH}$.

The analysis shows that shareholdings in German manufacturing firms are indeed highly concentrated in the hands of very few shareholders. The average size of the largest share block is over $81 \%$ in 1998 . From this perspective, agency costs should be small. However, in the majority of firms the largest shareholder is another non-financial firm. Agency costs are therefore more likely to arise within the controlling shareholder. Second, ownership structures are not constant over time. Concentration of shares changes in about $75 \%$ of all listed firms. This suggests that there is an active market for corporate shares in Germany. Third, only the minority of firms is controlled through pyramids of owners. But about $40 \%$ of the shareholders that ultimately control a firms are non-financial enterprises - again an indicator of agency costs resulting from agency conflicts within the controlling shareholder. Finally, crossshareholdings are of minor relevance in German firms in terms of the number of firms ultimately controlled by these control systems. In terms of firm size the relevance of crossshareholdings increases slightly. This does not stand in contrast to the intense discussion of 
cross-shareholdings in Germany because this study focuses on the manufacturing sector and the estimates on cross-ownership represent only lower bounds. 


\section{Introduction}

Corporate ownership structures around the world are very diverse but there seem to be two distinct groups (LA PORTA et al. 1999). In the Anglo-Saxon countries the majority of shares is widely held, whereas in continental Europe shares tend to be concentrated in the hands of a few large shareholders. ${ }^{1}$ For Germany, empirical studies report large share blocks and crossownership of firms (ADAMS 1994, WENGER and KASERER 1997, BECHT and BÖHMER 1999).

The ownership structure of firms is an important element of corporate governance - the complex system of legal, institutional and market forces by which firms are governed (BERLE and MEANS 1932). ${ }^{2}$ Economic theory suggests that large shareholders have the power and the incentives to monitor management and to press for value maximization (SHLEIFER and VISHNY 1986). On the other hand, when protection of minority shareholders is weak they might be exploited by large shareholders. The classical problem of corporate governance - the minimization of agency costs resulting from a separation of ownership and control (JENSEN and MECKLING 1976: 328) - also depends on the type of the shareholders. Corporate shareholders have internal agency conflicts and might therefore be weak monitors (VON THADDEN 1990). Likewise, pyramid structures and cross-shareholdings might limit efficient monitoring of managers (BEBCHUK ET AL 1998).

The empirical evidence for Germany on the relationship of ownership structure and shareholder value is limited and often contradicting. ${ }^{3}$ Descriptive evidence, however, on the German ownership structure is accumulating. BÖHMER (1998) and BECHT and BÖHMER (1999) analyze the ownership structure of the listed Aktiengesellschaft $(A G),{ }^{4}$ one form of a Kapitalgesellschaft, ${ }^{5}$ in detail but only on the first level of ownership. KAMMERATH (1999) provides valuable information on a much wider sample of all large German firms. BEYER (1998) 6cuses on pyramids and cross-shareholdings of German firms. But both studies neglect changes in the ownership structure over time.

\footnotetext{
${ }^{1}$ See PROWSE (1994) and FRANKS and MAYER (1995) for international comparisons.

${ }^{2}$ See SHORT (1994) for a survey of empirical studies examining the effect of ownership structure on performance.

${ }^{3}$ See CABLE (1985), NiBLER (1995), GORTON and SCHMID (1996) and SEGER (1997).

${ }^{4}$ Public company with limited liability.

${ }^{5}$ Company with limited liability which is generally run by managers who are not the single owners.
} 


\section{New Questions}

Ownership structures are not necessarily constant over time. If they change, this might have an effect on corporate governance which should be considered in any empirical study. When ownership structures change over time but are treated as being constant this will bias estimates. ${ }^{6}$ DENIS and SARIN (1999) find for the US that changes in the ownership structure are closely linked to prior stock price performance and consecutive board changes.

Currently, we can identify several forces of change. Institutional investors have been increasing their participation in equity markets for two decades (BLOMMESTEIN 1998). Deregulation within the EU will free those investors from portfolio restrictions which could lead to a further increase in their investment activity. Founder succession - which is of particular importance in Germany (GERKE et al. 1995) - could change the composition of shareholders significantly. Finally, international competition and current concentration on so-called 'core competencies' could cause firms to divest peripheral activities which in turn would result in ownership changes. Here causality is not totally clear. But the study of the time changes in the ownership structure may provide additional insights into causality.

\section{Purpose of the Study}

The purpose of this study is to document the ownership structures of large German manufacturing firms. It tries to address several shortcomings of the previous German empirical literature: First, we include all types of firms in the legal form of a Kapitalgesellschaft in the analysis. ${ }^{7}$ We therefore have data on a large number of firms which are not listed on the stock exchange but are also likely to have agency conflicts. This increases sample size considerably. Second, we document the development of the ownership structures over the years 1994-1998 showing that they are not constant as often assumed. Third, we try to find the ultimate owners in complex ownership structures like pyramids. This is an essential approach when firms are governed through pyramids. Finally, we quantify cross-ownership and find that - contrary to the general perception - this issue is of minor relevance in the German manufacturing sector. However, our measure of cross-ownership represents only a lower bound.

The paper is organized as follows: Section 2 discusses why the ownership structure of firms theoretically affects corporate governance and what measures of ownership structure are suit-

\footnotetext{
${ }^{6}$ See HIMMELBERG et al. (1999) for formal evidence and an empirical example on this.

${ }^{7}$ These are: the listed/non-listed public company with limited liability (AG), the limited partnership on shares $(\mathrm{KGaA})$ and the private company with limited liability $(\mathrm{GmbH})$.
} 
able in this context. Section 3 describes the data source. Section 4 presents the results and discusses implications for the size of agency costs. Section 5 concludes with some implications for future research in the field of corporate governance, in particular in Germany.

\section{Measurement Concepts}

Economic theory suggests that the ownership structure of enterprises affects their performance. In this chapter we discuss the role of different dimensions of ownership structure: size of share blocks, types of shareholders, pyramids and cross-ownership and suggest empirical measures of ownership structure which are based on economic theory. We begin with a short discussion of the type of the firm which is relevant for corporate governance analysis. We also discuss the impact of other firm-specific characteristics (legal form or going public) on the role of ownership structures and their effects on agency costs.

\subsection{Legal Form and Going Public}

From the theoretical perspective, any firm with a separation of ownership and control should be included in a study on corporate governance (JENSEN and MECKLING 1976). For Germany this means to focus on Kapitalgesellschaften ${ }^{8}$ because these firms, in contrast to partnerships and single proprietorships, generally are run by managers who only own small ownership stakes - if at all. ${ }^{9}$ There are two legal forms for a Kapitalgesellschaft: the $\mathrm{GmbH}^{10}$ (private company with limited liability) and the $\mathrm{AG}^{11}$ (public company with limited liability). The AG can be listed on the stock exchange whereas the GmbH cannot. ${ }^{12}$

Many firm-specific factors theoretically influence the size of agency costs. ${ }^{13}$ The structure of ownership on which we focus here is one of them. But also the legal form and the decision to go public could affect agency costs. ${ }^{14}$ In the $\mathrm{GmbH}$ owners can monitor their managers much closer than in the AG. ${ }^{15}$ But shares of an AG are easier to trade than shares of a GmbH, espe-

\footnotetext{
${ }^{8}$ A Kapitalgesellschaft is a company with limited liability which is generally run by managers who are not the single owners.

${ }^{9}$ There is no agency problem only when a firm is 100 percent owned by a single shareholder who is at the same time the only manager. He also must be an individual. This issue will be discussed in detail below.

${ }^{10}$ Gesellschaft mit beschränkter Haftung $(\mathrm{GmbH})$.

${ }^{11}$ Aktiengesellschaft (AG).

12 Two other legal forms are of minor importance: the GmbH \& Co. KG (a mixture of a partnership and a Kapitalgesellschaft) and the $\mathrm{KGaA}$ (a partnership that emitted tradable shares).

${ }^{13}$ See SHLEIFER and VISHNY (1997) for an excellent survey on these factors.

${ }^{14}$ See STEINER (1998) on the choice of a legal form and its consequences.

15 The general meeting of shareholders can give directions to the management in the GmbH.
} 
cially when the AG is listed on the stock exchange. This makes monitoring by 'exit' more attractive compared to monitoring by 'voice' as in the GmbH. In turn, new capital is easier to raise by a listed AG in the stock market. Wealth of shareholders put a constraint on this in the GmbH. ${ }^{16}$ A downside of an AG might be that an internal control institution, the Aufsichtsrat ${ }^{17}$, is required. This potentially reduces the voice of the original owner. Efficient control might be hindered because workers have a right to sit on that board. ${ }^{18}$ This could disturb homogeneity of interests on the board. ${ }^{19}$ The potential advantage of the $\mathrm{GmbH}$ of not having to have an Aufsichtsrat disappears when the $\mathrm{GmbH}$ exceeds a certain size.

Agency costs might be different in the GmbH than in the AG. If a particular legal form or the decision to go public is chosen by the owner this will be the result of a complex optimization problem in which agency costs constitute only one element. ${ }^{20}$ Therefore, ownership structures as described below must be interpreted cautiously. They as well as the choice of the legal form can be the result of an optimization problem and need not influence agency costs per se. For example, trading of shares on a stock exchange could lead to dispersion of shares in the listed AG. Then the ownership structure is endogenous.

\subsection{Size of Share Blocks}

SHLEIFER and VISHNY (1986) use the size of the largest share block as a measure of ownership. They argue that only in the presence of a large minority shareholder takeovers can be an effective disciplining device. ${ }^{21}$ When all shares are dispersed initially, free-riding of small shareholders will make any takeover attempt unattractive (GROSSMAN and HART 1980). But concentration of shares also has costs. DEMSETZ and LEHN argue (1985) that large shareholders are not diversified and hence bear excessive risk. A growing literature discusses expropriation of small minority shareholders by a large shareholder. Large owners who are also the managers can have full control over the firm's assets but not share in all the costs they generate. If they are wealthy enough they might prefer private benefits to maximization of firm value. ${ }^{22}$ Our preferred measure of the voting power of the largest shareholder is the size of the

\footnotetext{
${ }^{16}$ See BOLTON and VON THADDEN (1996) on the decision to go public and its implications for control.

${ }^{17}$ Board of directors.

${ }^{18}$ The participation of workers depends on the size and the industry of the firm.

${ }^{19}$ See HOPT (1998) for a critical analysis of the two-tiered German boards.

${ }^{20}$ Taxes and liability play no role in this decision because they are identical for all forms of the Kapitalgesellschaft. Disclosure requirements depend on firm size. But most firms covered in this analysis are large.

${ }^{21}$ See FRANKS and MAYER (1994) who find that large shareholders are associated with higher turnover of directors in Germany.

${ }^{22}$ See MORCK et al. (1988) for empirical evidence for the US.
} 
largest share block $\left(\mathrm{C}_{1}\right) .{ }^{23}$ However, we calculate some additional measures: the combined share stake of the two and three largest shareholders $\left(\mathrm{C}_{2}\right.$ and $\mathrm{C}_{3}$ respectively) to get an idea of the upper distribution of the ownership structure. Second, we use an approximation of the Herfindahl index to measure absolute concentration of shares and to allow for comparison with other studies. ${ }^{24}$ Third, we calculate a measure of the voting power of the largest shareholder as suggested by CUBBIN and LEECH (1983). ${ }^{25}$ It approximates the probability that the largest shareholder can win a vote given that small shareholder might oppose. ${ }^{26}$ Definitions of all measures are summarized in the appendix.

\subsection{Type of Shareholders}

A second dimension of ownership structure is the type of the shareholders. In the center of corporate governance analysis stands the distinction between dispersed and concentrated shareholdings. Although dispersion of shares is rather a matter of size of share blocks as discussed above we treat dispersed shares as one type of shareholder. In contrast to previous empirical studies, our definition of dispersed shares does not depend on the size of the largest block. ${ }^{27}$ We treat shares only then as dispersed when they are dispersed according to our database. $^{28}$

Individuals can be good monitors in comparison to corporate shareholders because they do not have any internal agency conflicts. Corporate shareholders substitute one agency conflict with another (VON THADDEN 1990). In turn, since individuals usually face wealth constraints they might be too risk-averse. Wealthy and well-diversified corporate shareholders could induce more efficient investment decisions.

The group of corporate shareholders is diverse. For example, creditors as shareholders might force a company to forego good investment opportunities because they focus on the downside of the earnings distribution (MYERS 1977). Insurance companies or universal banks which have regular business relationships besides their investment are unlikely to oppose management (POUND 1988). This also applies to non-financial firms as shareholders. Pension funds,

\footnotetext{
${ }^{23}$ This is a valid proxy when the largest shareholder holds more than 50 percent of the shares in most firms.

${ }^{24}$ This is a lower bound of concentration because we do not have data on all shareholder (e.g. dispersed shares).

${ }^{25}$ When the largest share block $C_{1}$ is over 50 percent (as is the case here), the difference between absolute and relative measures of concentration is negligible (FEUERSTACK 1999).

${ }^{26}$ See LEECH and LEAHY (1991) for an application of this measure on British firms.

${ }^{27}$ See SHORT (1994) for a review of the different definitions of dispersed versus concentrated shares applied in empirical studies.

${ }^{28}$ In a few cases ownership of shares does not add up to 100 percent. In these cases the rest was also treated as dispersed shares.
} 
on the contrary, with no business relationships to their investment objects might be good monitors. But the merits of institutional investors are highly debated. ${ }^{29}$ In the following we differentiate only between financial and non-financial enterprises because we have no consistent information on different types of financial enterprises.

Another type of shareholder is the state. SHAPIRO and WILLIG (1990) show that firms governed by bureaucrats should perform better under private management because bureaucrats lack the incentives to maximize shareholder value.

Finally, foreigners might exhibit a different control behavior than domestic investors. For example, institutional investors especially from the United States and Great Britain are very active institutional shareholders (SMITH 1996, CARLETON et al. 1998). Combined with their growing importance as a shareholder group (BLOMMESTEIN 1998) this makes a separate category for those shareholders desirable. ${ }^{30}$

In sum, we look at six different types of shareholders: dispersed shares, individuals, nonfinancial enterprises, financial enterprises, the state and foreigners.

\subsection{Pyramids and Cross-Ownership}

Third, we look at the vertical dimension of the shareholder structure. We do not only consider the first level of owners but also the owners of the owners. For Germany, pyramids and crossownership are the most important ownership structures. ${ }^{31}$

\footnotetext{
${ }^{29}$ See BLACK (1997), KARPOFF (1998) and DEL GUERCIO and HAWKINS (1999) for recent surveys on institutional investor activism. See BLACK (1992) and BLAIR (1995) on the theoretical merits of this class of investors. See PORTER (1992) for critical arguments.

${ }^{30}$ The term 'foreigners' here and in the following refers to corporate foreigners only, both financial and nonfinancial. Data do not allow to consistently distinguish between these two foreign types of corporates.

${ }^{31}$ LA PORTA et al. (1999) document that pyramids are a worldwide phenomenon. On cross-shareholdings in Germany see ADAMS (1994), BEYER (1998) and KAMMERATH (1999).
} 


\subsubsection{Pyramids}

\section{Figure 1: Pyramid of Owners}

\section{Firm C \\ $50.1 \%$}

Firm B

$50.1 \%$

Firm A

In this pyramid firm $A$ is controlled by firm $B$ whereas firm $B$ is controlled by firm $C$, the ultimate owner. We define the ultimate owner as the shareholder who has full control over a firm (either direct through a share of over 50 percent or indirect through a control chain as depicted in Figure 1) and itself is not controlled by another majority shareholder. ${ }^{32}$ We define a pyramid as a control structure by which an ultimate owner controls another firm through a control chain of over 50 percent at each level with at least one intermediate firm. ${ }^{33}$

This kind of ownership structure can generate agency costs. First, control might be diluted within high pyramids when transaction costs affect the flow of information. Second, pyramids can serve large shareholders as a control device to expropriate minority shareholders. GROSSMAN and HART (1988) and HARRIS and RAVIV (1988) argue that pyramids generate a departure from the one-share-one-vote scheme. Large shareholders can divert cash flow to themselves rather than to pay it out to all shareholders. On the other hand, if we assume that cash flow is paid out to investors according to their voting rights, the ultimate shareholder in a pyramid might receive less cash flow than would be expected regarding only his actual voting power. To give an example, firm $\mathrm{C}$ in Figure 1 controls firm A but receives only a minority share of cash flow $(50.1 \%$ x $50.1 \%=25.1 \%)$. This could disrupt its incentives to control firm A efficiently (BEBCHUK et al. 1998). ${ }^{34}$ In sum, we use three measures to characterize pyra-

\footnotetext{
${ }^{32}$ A majority of 50 percent does not guarantee ongoing control. A majority of 75 percent is required to exchange management during its period of office ( $§ 103$ (1) AktG) or to incorporate a firm into the own firm ( $\S 2 \mathrm{ff}$. UmwG). But a 50 percent majority is sufficient to dismiss management after their regular period of office. A share much lower than 50 percent can be sufficient when the rest of the shares is dispersed or when the corporate charter limits the voting rights of minority shareholders. Without more detailed information 50 percent is the best proxy available.

${ }^{33}$ LA PORTA et al. (1999) use a share size of 10 percent and 20 percent at each level for 27 countries, RENNEBOOG (1996) share sizes of 25 percent, 50 percent and 75 percent for Be lgium.

${ }^{34}$ Full control over cash flow requires a majority of 75 percent ( $\S 2$ ff. UmwG). But when dividends are paid out relative to share size, share size can be used as a proxy for cash flow rights.
} 
mids: first, the level of ultimate control. Second, the measure proposed by BEBCHUK et al. (1998):

$$
\alpha=\prod_{i=1}^{N} P_{i}^{2}
$$

whereby $\mathrm{P}_{\mathrm{i}}$ is the controlling share on level $\mathrm{i}$, the share $\mathrm{P}_{\mathrm{i}}>50 \%$ and $\mathrm{N}$ is the ultimate level of control. Third, in order to see if there is a separation of cash flow and control as argued above we calculate the ratio of cash flow rights of the ultimate owner (the measure $\alpha$ ) to the size of the largest share block $\mathrm{C}_{1}$ on the first level of the pyramid. ${ }^{35}$

\subsubsection{Cross-Ownership}

Cross-ownership which is regularly discussed as a typical feature of the German ownership structure (e.g. WENGER and KASERER 1997, BEYER 1998) can generate so-called insidersystems' (FRANKS and MAYER 1995). These systems are characterized by a lack of control by outside investors. Insiders such as managers might not be held accountable because the firm is either widely-held or has large owners which are themselves partially owned by the firm in consideration. These two-way share linkages could hinder efficient monitoring.

We define that a firm is part of an insider-system when it directly or indirectly owns some fraction of its own shares. We further define that a firm is controlled by an insider-system when its ultimate shareholder is part of an insider-system. Our measure of an insider-system is the degree of cross-ownership: the cumulated fraction of shares a particular firm owns in $\mathbf{i}$ self. If cross-ownership is greater than zero we say that the particular firm is part of an insider-system. Figure 2 graphically illustrates an insider-system:

\section{Figure 2: Cross-Ownership}

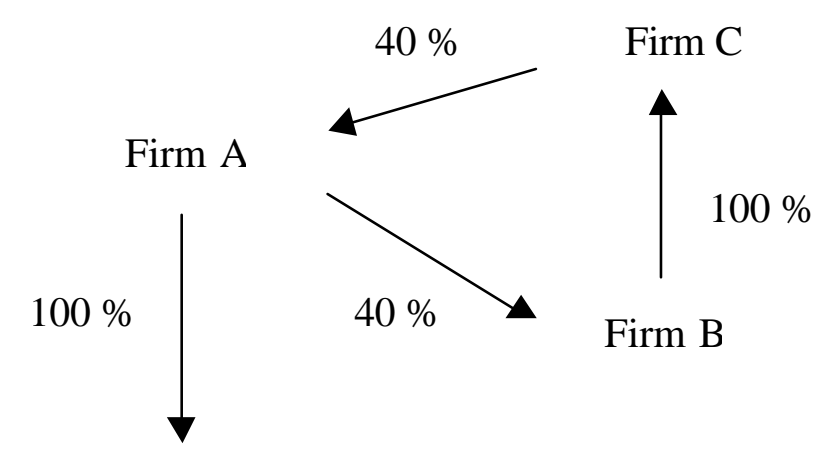

Firm D

\footnotetext{
${ }^{35}$ The share size on the first level is used as a proxy for the extent of control as desired by the ultimate owner.
} 
In Figure 2 firm A holds 40 percent of the shares in firm B which in turn holds 100 percent of the shares in firm $\mathrm{C}$, and firm $\mathrm{C}$ holds 40 percent of the shares in firm A. Therefore firm A (as well as firms B and C) is part of an insider-system because it owns 16 percent of its own shares, the degree of cross-ownership. Furthermore, firm D which is fully controlled by firm $\mathrm{A}$ is controlled by an insider-system because its ultimate shareholder, firm A, is part of an insider-system. Note that - in contrast to FRANKS and MAYER (1995) - we do not require that all firms in an insider-system hold shares of at least 50 percent in each other. Thus our definition of an insider-system is broader. The reason is that firms can use many other instruments to immunize themselves from the control of outsiders, e.g. multiple voting rights or caps on voting rights which are not reflected in the ownership structure of shares.

All definitions and measurement concepts of ownership structure discussed so far are summarized in the appendix.

\section{Data}

Firm-level data on ownership structures are obtained from the KONZERNSTRUKTURDATENBANK (KSD), a commercially available database. ${ }^{36}$ KSD has been existing since 1994. Each year four updates are released on CD-ROM. The 2/98 update, for example, contains 38,788 observations on German banks, insurance companies, non-financial companies, holding companies, capital investment companies, ${ }^{37}$ foundations, government authorities and ind ividuals. Further details can be found in KÖKE (1999).

Table 1: Descriptive Statistics on KSD (Update 2-1998)

\begin{tabular}{lcccccc}
\hline & AG & $\mathrm{GmbH}^{1}$ & KGaA & Other & Total & $\begin{array}{c}\text { Percent of Total } \\
\text { Population }^{2}\end{array}$ \\
\hline Observations & 2,340 & 20,835 & 29 & 15,584 & 38,788 & 1.40 \\
Percent of Total Population $^{2}$ & 96.89 & 5.04 & n.a. & n.a. & 1.40 & -- \\
\hline Sales $\geq 1$ million DM & 1,380 & 7,363 & 15 & 1,201 & 9,959 & 1.91 \\
Sales $\geq 10$ million DM & 1,246 & 6,680 & 15 & 1,018 & 8,959 & 13.90 \\
Sales $\geq 100$ million DM & 893 & 2,695 & 13 & 456 & 4,057 & 64.6 \\
\hline
\end{tabular}

Notes: ${ }^{1}$ Including GmbH\&Co.KG; ${ }^{2}$ Total population refers to data on the year 1996 taken from STATISTISCHES BUNDESAMT (1999). KGaA is included in AG, no aggregate data are available for GmbH\&Co.KG separately; therefore the percentages represent only a very rough estimate.

Source: KSD update 2-1998; STATISTISCHES BUNDESAMT (1999), Sales Tax Statistic, Table VIIb; own calculations.

\footnotetext{
${ }^{36}$ COMPANY STRUCTURE DATABASE form Verlag Hoppenstedt GmbH in Darmstadt/Germany; http://www.hoppenstedt.de.

${ }^{37}$ I.e. the German Kapitalanlagegesellschaften.
} 
As can be seen from Table 1, more than 23,200 firms in KSD are run in the legal form of a Kapitalgesellschaft. ${ }^{38}$ About 15,600 observations relate to partnerships, households, public municipalities etc. which are not subject of this study. Compared with the total German population coverage of the AG is very good (almost 97 percent) but only a small part of all GmbHs (about 5 percent) is contained in KSD. However, as firm size increases (measured by sales) coverage of KSD improves also for GmbHs. For example, KSD contains about 64.4 percent of firms with sales higher than 100 million DM for the year $1998 .{ }^{39}$

We collect data on five consecutive years (1994-1998) to get a better picture of the development of ownership structure over time. This is a new approach because previous studies on Germany only analyze a single year for analysis. We exclude all firms which are not a Kapitalgesellschaft. In addition, we focus on the manufacturing sector to allow comparisons with previous studies. After this selection procedure we obtain a sample of 5,788 observations for the years 1994-1998. About 90 percent of these firms are large in terms of German Trade Law (HGB), i.e. have sales over 32 million DM and balance sheet total over 15.5 million DM.

Table 2: Observations by Year and Legal Form

\begin{tabular}{lrrrrrrr}
\hline Year & GmbH & AG & \multicolumn{2}{c}{ KGaA } & \multicolumn{2}{c}{ Total } \\
\hline & & total & $\begin{array}{r}\text { thereof } \\
\text { listed }\end{array}$ & total & $\begin{array}{r}\text { thereof } \\
\text { listed }\end{array}$ & $\begin{array}{r}\text { total } \\
\text { thereof } \\
\text { listed }\end{array}$ \\
\hline 1994 & 528 & 341 & 167 & 2 & 1 & 871 & 168 \\
1995 & 576 & 361 & 175 & 2 & 1 & 939 & 176 \\
1996 & 613 & 398 & 196 & 3 & 2 & 1014 & 198 \\
1997 & 797 & 638 & 321 & 10 & 7 & 1445 & 328 \\
1998 & 843 & 666 & 348 & 10 & 7 & 1519 & 355 \\
\hline Total & 3357 & 2404 & 1207 & 27 & 18 & 5788 & 1225 \\
\hline Percent of all obser- & 58.00 & 41.53 & 20.85 & 0.47 & 0.31 & 100.00 & 21.16 \\
vations & & & & & & &
\end{tabular}

Note: The following editions of KSD were used: 3-1994, 2-1995, 2-1996, 1-1997, 2-1998.

The majority of firms has the legal form of the $\mathrm{GmbH}$ (58 percent) and about half of the AGs are listed on a stock exchange. Overall, only 21 percent of all observations are listed firms. Thus - in contrast to previous German studies - we have data on a large amount of firms which are also likely to have principal-agent conflicts but are not run as an AG or are not listed.

\footnotetext{
38 These are: AG, GmbH, GmbH\&Co.KG, KGaA.

${ }^{39}$ This is only a lower bound estimate because many firms in KSD do not have sales data.
} 


\section{Results}

Making use of the measurement concepts developed in section 2 we now describe the ownership structure of large German manufacturing firms run as a Kapitalgesellschaft.

\subsection{Size of Share Blocks}

German shareholdings are highly concentrated in the hands of only very few shareholders. Table 3 shows the largest share blocks $C_{1}, C_{2}$ and $C_{3}$ as defined in section 2.2 in the aggregate and by legal form.

Table 3: Size of Largest Share Block by Legal Form in $1998^{1}$

\begin{tabular}{lrrrr}
\hline in percent & GmbH & Non-Listed AG & Listed AG & Weighted Average $^{2}$ \\
\hline$C_{1}$ & 89.44 & 83.23 & 57.66 & 81.06 \\
$C_{2}$ & 96.06 & 90.76 & 65.15 & 88.07 \\
$C_{3}$ & 97.08 & 92.14 & 67.69 & 89.50 \\
\hline Number of Observations $^{3}$ & 841 & 312 & 325 & 1486 \\
\hline
\end{tabular}

Note: ${ }^{1}$ The measure could not be calculated for 33 observations because only dispersed shares were recorded for these. ${ }^{2}$ Including KGaA. ${ }^{3}$ The $\mathrm{KGaA}$ is not reported here as a separate category because the number of observations is only 8 .

In 1998, the largest share was very high with 81.1 percent on average. Adding the shares of the second and third largest shareholder their combined holdings increased to almost 90 percent. Differentiating by legal form shows that in the $\mathrm{GmbH}$ the average largest share is about 32 percentage points higher than in the listed AG. Together the three largest shares make up over 97 percent. Comparing the listed versus the non-listed AG we see that the average largest share in the listed AG is much lower than in the non-listed AG.

These numbers are very high compared with US enterprises but also compared with firms in other European countries. ${ }^{40}$ Descriptive evidence can be found in BECHT (1997) for the US, CRESPI (1997) for Spain, DE JONG et al. (1997) for the Netherlands and BIANCHI et al. (1997) for Italy. ${ }^{41}$

Due to the theoretical importance of the largest shareholder we choose the measure $\mathrm{G}$ for closer scrutiny. Figure 3 shows the density function of $\mathrm{C}_{1}$ for the listed AG.

\footnotetext{
40 The cumulated share of the three largest shareholders is: $42 \%$ in the US (BECHT 1997), 57.5\% in Spain (CRESPI 1997), 31.4\% in the Netherlands (DE JONG et al. 1997) and 89.8\% in Italy (BIANCHI et al. 1997).

${ }^{41}$ Evidence on other European countries see ECGN (1997).
} 


\section{Figure 3: Density Function of Largest Share Block C1}

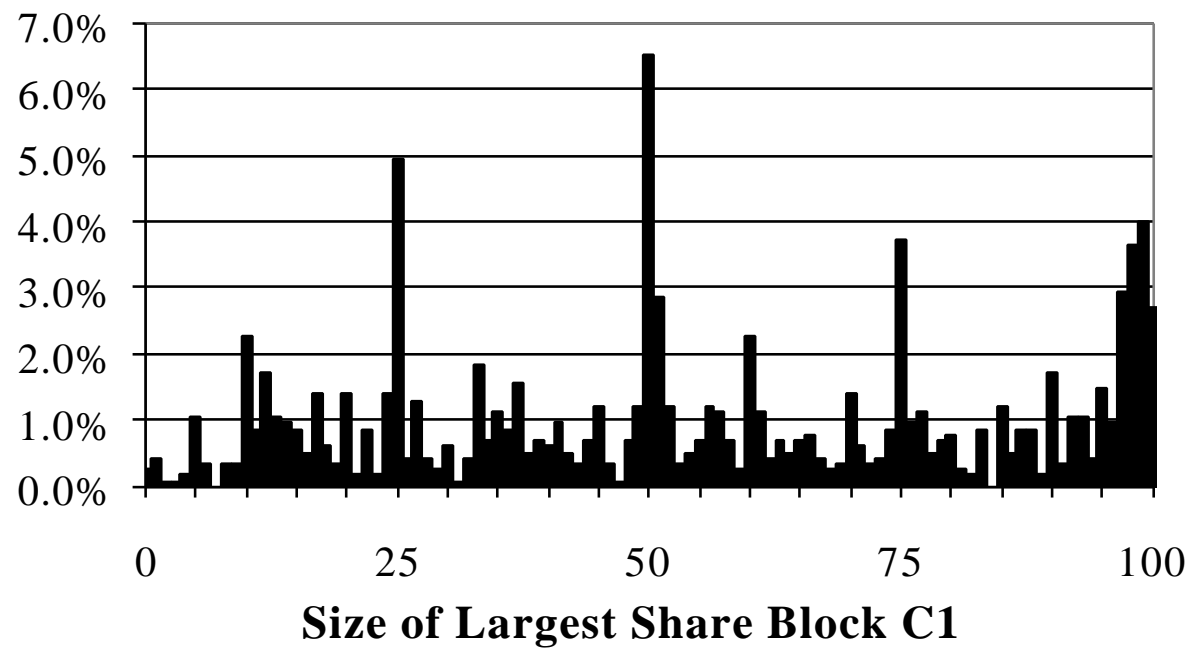

Note: Data for 1994-1998 on the listed AG.

In Germany specific shareholder rights are connected with specific block sizes. A share of 25 percent implies the right to veto proposed changes of the corporate charter. With a majority of 50 percent the shareholder can appoint and dismiss management ${ }^{42}$ and with a supermajority of 75 percent this shareholders' decisions are not endangered by a veto from minority shareholders. ${ }^{43}$ Figure 3 suggests that the size of the largest share is influenced by these legal rights. In other words, shareholders tend to buy that amount of shares which is necessary for control purposes.

Table 4: Cumulative Distribution of Largest Share Block $\mathbf{C}_{1}$

\begin{tabular}{lrrrr}
\hline in percent & GmbH & Non-Listed AG & Listed AG & Weighted Average $^{2}$ \\
\hline$\geq 99 \%$ of shares & 71.03 & 56.76 & 6.69 & 54.87 \\
$\geq 90 \%$ of shares & 75.74 & 64.53 & 20.33 & 62.04 \\
$\geq 75 \%$ of shares & 79.55 & 70.19 & 33.10 & 68.03 \\
$\geq 50 \%$ of shares & 93.74 & 88.01 & 59.77 & 85.61 \\
$\geq 25 \%$ of shares & 98.00 & 95.69 & 82.28 & 94.28 \\
\hline Number of Observations & 3355 & 1151 & 1184 & 5712 \\
\hline
\end{tabular}

Note: ${ }^{1}$ The measure could not be calculated for 76 observations because only dispersed shares were recorded for these. ${ }^{2}$ Including KGaA. ${ }^{3}$ The $\mathrm{KGaA}$ is not reported here as a separate category because the number of observations is only 22 .

Table 4 shows how many of the sample firms have a large shareholder and what the size of $\mathrm{C}_{1}$ is. We see that in 54.9 percent of all firms the largest shareholder holds 99 percent or more of

\footnotetext{
${ }^{42}$ For regular elections of the board a 50 percent majority is required in the AG. For elections before the regular end of the period of office a 75 percent majority is required ( $\$ 103$ (1) AktG)

${ }^{43}$ Even smaller share sizes can provide a sufficient majority when the corporate charter contains voting right restrictions. However, they are illegal from the year 2000 on (WpHG).
} 
the shares. Thus the majority of firms is controlled by a single owner. From this perspective, agency problems resulting from expropriation of small shareholders through large shareholders are unlikely because most firms do not have any minority shareholders. In over 85.6 percent of the firms the largest shareholder owns 50 percent or more of the shares. Thus most firms have a large shareholder - which is very large in comparison with UK and US shareholders $^{44}$ - that could govern the firm efficiently. But the quality of monitoring also depends on the type of the largest shareholder.

Table 4 also shows that - on average - the largest shareholder is relatively small in the listed AG. In only 6.7 percent of the listed AGs he holds 99 percent of the shares or more, compared to 56.8 percent of the non-listed AGs and 71 percent of the GmbHs. Almost 60 percent of the firms listed on the stock exchange have a shareholder that holds 50 percent and more of the shares. The numbers for the non-listed AG and the GmbH are even higher: 88 percent and 93.7 percent respectively. From this perspective it seems reasonable to analyze primarily the listed AG because agency costs resulting from weak control by the dominant shareholder might be the highest here.

\section{Table 5: Concentration of Shares: Herfindahl and Cubbin \& Leech Indices}

\begin{tabular}{|c|c|c|c|c|}
\hline & $\mathrm{GmbH}$ & Non-Listed AG & Listed AG & Weighted Average $^{1}$ \\
\hline Herfindahl Index & 0.856 & 0.769 & 0.403 & 0.741 \\
\hline $\begin{array}{l}\text { Percent of Observations with Vot- } \\
\text { ing Power Index }=1\end{array}$ & 85.25 & 80.79 & 62.30 & 79.35 \\
\hline Number of Observations ${ }^{2}$ & 3357 & 1197 & 1207 & 5788 \\
\hline
\end{tabular}

Table 5 confirms that $\mathrm{GmbH}$ shares are highly concentrated since the Herfindahl index (which ranges from zero to one $)$ is very high $(\mathrm{H}=0.856)$. Concentration in the non-listed $A G$ is lower $(\mathrm{H}=0.769)$ and the lowest in the listed $\mathrm{AG}(\mathrm{H}=0.403)$. Likewise, the measure of voting power developed by CUBBIN and LEECH (1983) indicates that the largest shareholder is likely to decide a vote for himself in 62.3 percent of the listed AGs and over 80 percent in both types of unlisted firms.

\section{Changes in Size of Share Blocks}

Previous German studies neglect changes in the ownership structure. Figure 4 addresses this issue.

\footnotetext{
${ }^{44}$ See BECHT (1997) for the US and FRANKS and MAYER (1994) for the UK.
} 
Figure 4: Changes in the Herfindahl Concentration Index (1994-1998)

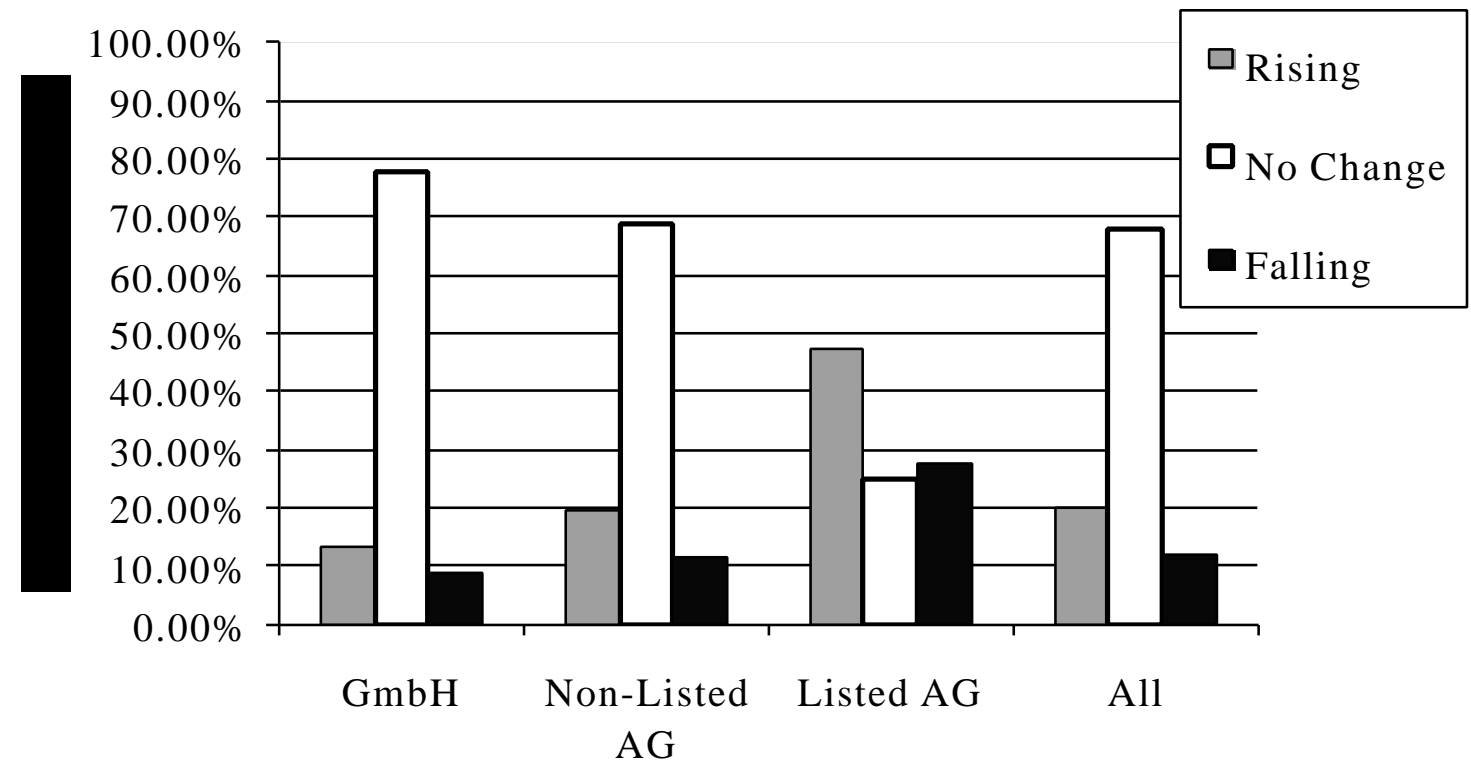

Figure 4 depicts the mean change in concentration as measured by the Herfindahl index per firm. Concentration rises in about 20 percent and falls in about 12 percent of firms, but it is constant in the large majority of firms (68.0 percent). From this perspective, the selection of a single year to describe the ownership structure of a firm - as not only previous German studies do - should not generate a significant bias because ownership structures seem fairly stable. However, when a distinction is made between the two legal types of firms and between listed versus non-listed firms the assumption of stable ownership structures cannot be maintained, particularly not for listed firms. Almost half of the firms being traded on the stock exchange exhibit increasing shareholder concentration over the last five years (47.2 percent). At the same time, more than a quarter of those firms show a decreasing concentration of shares $(27.8$ percent). Concentration of shares does not change in the majority of non-listed firms. Firmspecific concentration changes in 20-30 percent of these firms.

Table 6: Median Annual Growth Rates in the Herfindahl Index (1994-1998) ${ }^{1}$

\begin{tabular}{lrrrr}
\hline & GmbH & Non-Listed AG & Listed AG & Weighted Average $^{2}$ \\
\hline Rising & 2.17 & 2.27 & 0.80 & 1.44 \\
No Change & 0.00 & 0.00 & 0.00 & 0.00 \\
Falling & -1.23 & -1.31 & -1.41 & -1.29 \\
\hline Number of Observations $^{3}$ & 2932 & 939 & 706 & 4592 \\
\hline
\end{tabular}

Note: ${ }^{1}$ Median annual growth rate in firm-specific Herfindahl index whereby the firm-specific index is the geometric mean per firm. Excluded were firms that had over $50 \%$ of shares with no clearly identified type of shareholder because this would bias the concentration measure. ${ }^{2}$ Including $\mathrm{KGaA} .{ }^{3}$ The $\mathrm{KGaA}$ is not reported here as a separate category because the number of observations is only 15.

Table 6 gives a rough impression of the relative magnitude of the changes in share concentration. The median annual increase is higher than the median annual decrease in firm-specific 
share concentration. Combined with the results from Figure 4 this suggests that share concentration increased over the years 1994-1998. This result holds for the non-listed firms because the positive median change is stronger than the negative median change, while at the same time more non-listed firms increased than decreased share concentration. For the listed AG the results are ambiguous because more firms increased than decreased share concentration but - in the median - the negative change is stronger than the positive change.

In sum, shareholder concentration is high for all types of firms. From this perspective, agency costs could be small due to the absence of a separation of ownership and control or good monitoring by the large shareholder. Ownership structure as measured by share concentration is fairly stable. ${ }^{45}$ But in about one third of the firms concentration increases or decreases. Changes particularly occur in the listed AG. Whether the neglect of changes in ownership structures produces a bias in empirical studies must be examined by further research. ${ }^{46}$

\subsection{Type of Shareholders}

We next classify shareholders into the six groups defined in section 2.3: dispersed shareholdings, individuals, non-financial firms, the state, financial enterprises and foreigners. In 1998, on average, the largest group of shareholders were non-financial enterprises with a share of 65.1 percent (Table 7). Foreigners hold about 11.1 percent and individuals 7.9 percent of outstanding shares. In contrast to the influential role assigned to banks in various studies on German corporate governance ${ }^{47}$ stands their - on average - very low share of 1.9 percent. However, banks' voting power is potentially much greater due to the specific system of proxy voting, widespread membership of bankers on boards and their role as creditors. ${ }^{48}$

\footnotetext{
${ }^{45}$ Changes in the shareholder structure which do not lead to changes in share concentration are neglected here. We therefore estimate only a lower limit of all changes.

${ }^{46}$ A bias would occur if the changes in the ownership structure were not random but would be caused by an exogenous variable which also influences performance measures.

${ }^{47}$ See for example NiBLER (1995) and GORTON and SCHMID (1996).

${ }^{48}$ See BAUMS and FRAUNE (1995) on banks' voting power through proxy votes and PFANNSCHMIDT (1993) on personal interlockings. Taking into account these additional sources of bank influence EDWARDS and FISCHER (1994) still reject the hypothesis of strong bank power in corporate governance.
} 
Table 7: Shareholder Structure by Type and Legal Form

\begin{tabular}{lrrrr}
\hline in percent & GmbH & Non-Listed AG & Listed AG & Weighted Average $^{1}$ \\
\hline 1 Dispersed Shares & 3.99 & 9.2 & 36.1 & 11.92 \\
2 Individuals & 4.00 & 15.39 & 10.79 & 7.85 \\
3 Non-Financial Firms & 75.57 & 62.63 & 39.55 & 65.14 \\
4 State & 3.04 & 2.11 & 1.04 & 2.41 \\
5 Financial Enterprises & 0.40 & 1.52 & 6.45 & 1.93 \\
6 Foreigners & 13.00 & 9.15 & 6.07 & 10.75 \\
\hline Total & 100.00 & 100.00 & 100.00 & 100.00 \\
Number of Observations $^{2}$ & 843 & 348 & 318 & 1519 \\
\hline
\end{tabular}

Notes: ${ }^{1}$ Including KGaA. ${ }^{2}$ The $\mathrm{KGaA}$ is not reported here as a separate category because the number of observations is only 27 .

Table 7 describes the aggregate shareholder structure, i.e. the fraction of shares which is owned by a particular type of shareholder. Most shares are held by non-financial firms in listed and non-listed firms. A relatively high fraction is dispersed in the listed AG, whereas dispersion is low in firms that did not go public. Dispersion of shares is of course a consequence of the decision to go public. The role of individuals as direct shareholders is small, looking at the fraction of all shares in their hands. They hold about 15.4 percent of the shares in the non-listed AG, 10.8 percent in the listed AG, and only 4 percent in the $\mathrm{GmbH}$.

This aggregate shareholder structure does not necessarily reflect actual voting power of the individual types of shareholders. Therefore we look at the type of the largest shareholder in each firm-year. Since the largest shareholder is not always large enough to dominate all decisions, ${ }^{49}$ we additionally check whether the largest shareholder fulfills the voting power criterion of CUBBIN and LEECH (1983). ${ }^{50}$ If the largest shareholder does not fulfill this criterion, the respective observation is grouped as dispersed shares.

\footnotetext{
${ }^{49}$ For example, the largest shareholder holds 51 percent, the second largest shareholder 49 percent. Then the position of the largest shareholder is much weaker compared to a 99 percent stake in his hands.

${ }^{50}$ See section 4.1 .
} 
Table 8: Shareholder Structure: Largest Shareholders by Type ${ }^{1}$

\begin{tabular}{lrrrr}
\hline in percent & GmbH & Non-Listed AG & Listed AG & Weighted Average $^{2}$ \\
\hline 1 Dispersed Shares & 14.75 & 19.21 & 37.70 & 20.65 \\
2 Individuals & 2.83 & 11.78 & 10.60 & 6.39 \\
3 Non-Financial Firms & 67.92 & 58.81 & 41.18 & 60.25 \\
4 State & 2.80 & 1.59 & 0.83 & 2.13 \\
5 Financial Enterprises & 0.18 & 0.42 & 3.81 & 0.98 \\
6 Foreigners & 11.53 & 8.19 & 5.88 & 9.61 \\
\hline Total & 100.00 & 100.00 & 100.00 & 100.00 \\
\hline Number of Observations $^{3}$ & 3357 & 1197 & 1207 & 5788 \\
\hline
\end{tabular}

Notes: ${ }^{1}$ Type of largest shareholder that is classified as having voting power using the CUBBIN and LEECH (1983) index. All firms with no large shareholder (just dispersed shares) or those having no large shareholder with voting power using the CUBBIN and LEECH index are classified as "dispersed". ${ }^{2}$ Including KGaA. ${ }^{3}$ The $\mathrm{KGaA}$ is not reported here as a separate category because the number of observations is only 27.

More than 60 percent of the firms are governed by a large shareholder that is another nonfinancial firm. These shareholders have not only large stakes. They also have high voting power due to the small size of other shareholders in their firms. About 20 percent of the firms can be classified as widely-held what is much more than indicated by Table 7. Foreigners dominate almost 10 percent of German manufacturing firms by vote, whereas individuals govern only about 6.4 percent of all firms. The state controls about 2 percent of all firms.

Looking at the three different forms of firms we see differences in the shareholder structure. More than one third of the firms traded on the stock exchange is widely-held but only 14.8 percent of the $\mathrm{GmbH}$ and 19.2 percent of the non-listed AG. Non-financial firms control almost 68 percent of GmbH firms, almost 60 percent of non-listed AGs and more than 41 percent of the listed AGs. Financial enterprises govern about 4 percent of the listed AGs; in the non-listed firms their influence is small. On aggregate, foreigners play only a minor role as shareholders. The difference between the three types of firms indicates that foreign investors prefer to invest in a $\mathrm{GmbH}$ rather than in a listed AG. Indeed, many of the foreign investments in $\mathrm{GmbHs}$ are 100 percent subsidiaries. Thus, full control seems to be important for a foreign direct investment in Germany.

\section{Changes in Type of Shareholders}

Figure 5 gives more evidence on changes in the ownership structure. 
Figure 5: Changes in the Share Held by Each Type of Shareholder (1994-1998)*

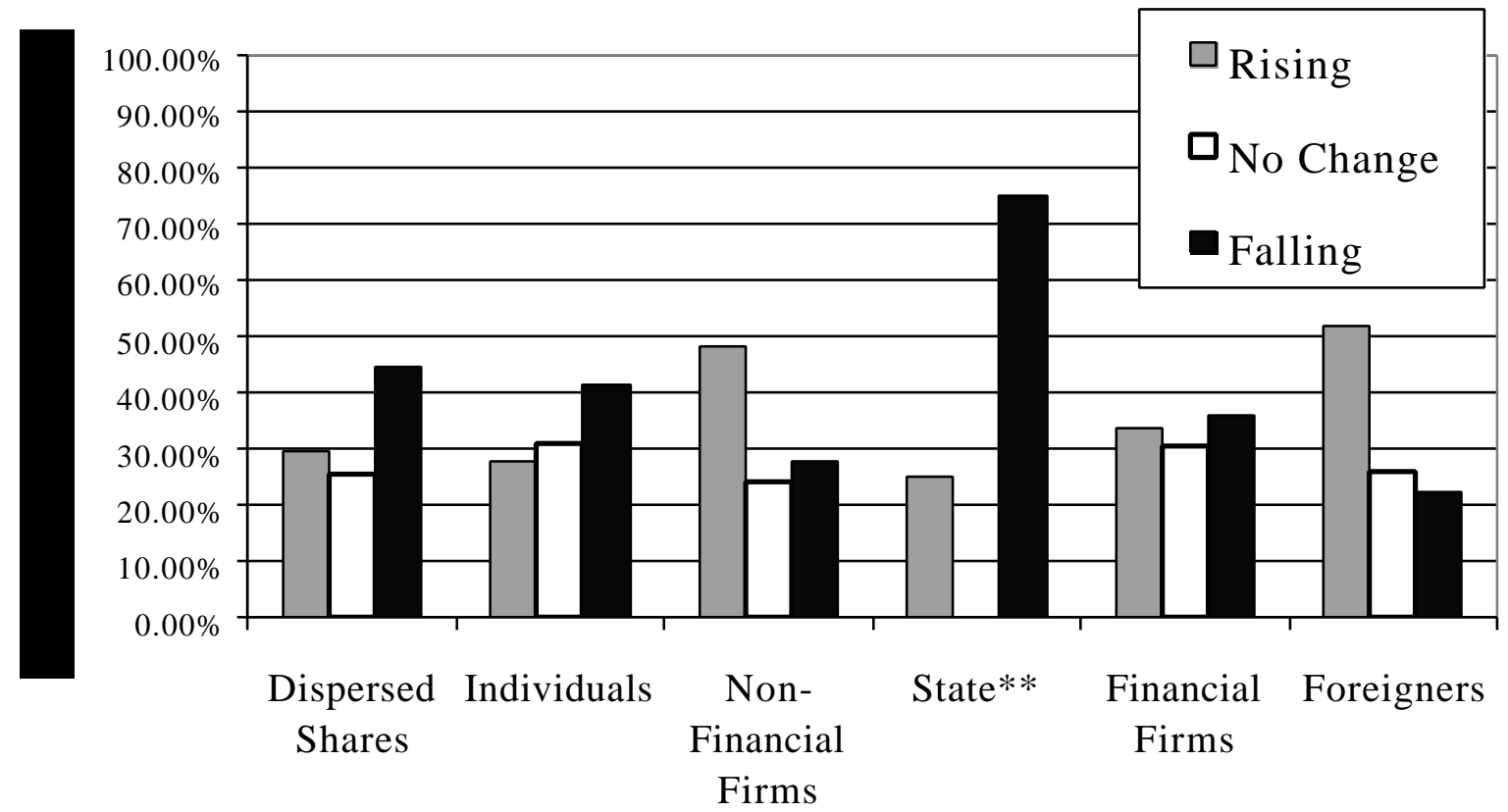

\section{Type of Shareholder}

Note: * Percentage of firms in which shareholder type $\mathrm{x}$ holds a share block larger than zero at least in one year during the period 1994-1998 and in which the mean annual change is different from zero. Depicted for the case of the listed AG. Excluded are firms that have over $50 \%$ of shares with no clearly identified type of shareholder and firms for which we do not have a continuous history of data without missing values. ${ }^{* *} 0 \%$ have no change.

Figure 5 depicts the changes in each shareholder category for the period from 1994 to 1998. For example, given that non-financial firms own a share block in a firm, they do not change the size of this share block in only 25 percent of the cases. Rather, in 48 percent they increase the size of their block and decrease its size in 27.7 percent of the firms they are invested in. The state, in turn, changes the size of all its share blocks. Only non-financial firms and foreigners increase rather than decrease the size of their blocks.

Table 9: Median Annual Change in Each Shareholder Category (1994-1998) ${ }^{1}$

\begin{tabular}{|c|c|c|c|c|c|c|}
\hline & $\begin{array}{r}\text { Dispersed } \\
\text { Shares }\end{array}$ & Individuals & $\begin{array}{c}\text { Non-Financial } \\
\text { Enterprises }\end{array}$ & State & $\begin{array}{r}\text { Financial } \\
\text { Enterprises }\end{array}$ & Foreigners \\
\hline Rising & 2.60 & 11.04 & 0.88 & 6.30 & 5.70 & 8.00 \\
\hline No Change & 0.00 & 0.00 & 0.00 & 0.00 & 0.00 & 0.00 \\
\hline Falling & -1.05 & -6.00 & -8.60 & -11.25 & -2.50 & -8.33 \\
\hline $\begin{array}{l}\text { Number of } \\
\text { Obs. }\end{array}$ & 728 & 211 & 577 & 20 & 200 & 139 \\
\hline
\end{tabular}

Table 9 provides quantitative details on the changes in share blocks held by each category of shareholder. For example, individuals that increase their share blocks during 1994-1998 do this by about 11 percent. The median annual increase in the share blocks held by nonfinancial firms is comparatively low with 0.9 percent, whereas the decrease is rather high with 
-8.6 percent. The decrease is smaller in size with -6 percent. Figure 5 and Table 9 also reflect recent privatization: the state decreased 75 percent of its share blocks and reduced their size by about -11.3 percent annually. Overall, we see that changes in the size of the share blocks are significant in size. These changes in the shareholder structure can also be found for the non-listed firms but the frequency of changes is lower. In turn, the magnitude of changes is higher.

What can be learned from this section is that non-financial enterprises are often the largest and the decisive shareholder. And there are differences in the shareholder structure between listed and non-listed firms. Differences can also be found among non-listed firms. Second, there is evidence of significant changes in the shareholder structure in terms of shareholder type even over the short period of five years. Third, these changes are not uniform over the three types of firms. Since ownership structure is not constant over time these changes in the ownership structure must enter empirical studies of corporate go vernance.

\subsection{Pyramids and Cross-Ownership}

The third characteristic of ownership structure besides the size and type of individual stakes is the location of control as defined in section 2.4. Table 10 shows the level of ultimate control, i.e. the end of a continuous 50 percent-stake control chain.

\section{Pyramids}

Table 10: Level of Ultimate Control

\begin{tabular}{lrrrrrrr}
\hline & 1 & 2 & 3 & 4 & 5 & 6 & Total \\
\hline Number of Obs. & 2527 & 1478 & 494 & 128 & 8 & 3 & 4638 \\
Percent of Total & 54.48 & 31.87 & 10.65 & 2.76 & 0.17 & 0.06 & 100.00 \\
\hline
\end{tabular}

Note: Necessary condition for control is a share size of over $50 \%$ on each level in the control chain.

In the majority of firms the ultimate owner is located on the first level of the ownership structure. This suggests that the agency problem resulting from dilution of control in the pyramid might be low. Only 13.6 percent of the firms are governed through a pyramid with at least three levels. Among the three types of firms the $\mathrm{GmbH}$ has the longest control chains. Out of the 633 observations with a level of ultimate control above 2 over 82 percent are in the form of the $\mathrm{GmbH}$. This indicates that the $\mathrm{GmbH}$ is the preferred legal form to construct pyramids.

It must be noted, however, that we eventually underestimate the size of the pyramids because control chains are not always complete in KSD. 
Table 11: Ultimate Shareholder versus Dominant Shareholder on First Level by Type

\begin{tabular}{lrrrrrrrr}
\hline in percent & Dispersed & $\begin{array}{r}\text { Indi- } \\
\text { viduals }\end{array}$ & $\begin{array}{r}\text { Non-Financial } \\
\text { Enterprises }\end{array}$ & State & $\begin{array}{r}\text { Financial } \\
\text { Enterprises }\end{array}$ & $\begin{array}{r}\text { Foreign- } \\
\text { ers }\end{array}$ & $\begin{array}{r}\text { Total } \\
\text { Number } \\
\text { of Obs. }\end{array}$ \\
\hline $\begin{array}{l}\text { First level } \\
\text { Ultimate }\end{array}$ & 20.65 & 6.39 & 60.25 & 2.13 & 0.98 & 9.61 & 100.00 & 5788 \\
level $^{2}$ & 27.79 & 9.95 & 41.59 & 3.09 & 0.74 & 16.84 & 100.00 & 5788 \\
\hline
\end{tabular}

Note: ${ }^{1}$ Dominant shareholder on first level by type as shown in Table $7 .{ }^{2}$ Ultimate shareholder classified according to voting power index as done in Table 7.

Table 11 shows the type of the largest shareholder - both on the first level and on the ultimate level. Both measures are corrected with the voting power index, i.e. the dominant shareholder, if existent, can decide a vote with a probability of 95 percent. For example, in 60.3 percent of the firms the dominant shareholder on the first level is a non-financial firm. On the ultimate level, in 41.6 percent of the firms the ultimate shareholder fulfills this voting criterion. As to be expected, ownership by corporate shareholders is lower on the ultimate than on the first level. However, a substantial part of the firms remain in full control by non-financial firms. In part, this is due to limited data. But it also reflects the fact that non-financial firms have a strong ultimate voting power which is not subject to control by any individual shareholder. ${ }^{51}$

Cash flow rights of the ultimate shareholder can serve as an indicator of the size of another agency problem: the exploitation of minority shareholders by a majority shareholder. Calculation of the measure suggested by BЕBCHUK et al. (1998) shows that in 97.6 percent of the firms the ultimate shareholder receives over 50 percent of the cash flow. Only in 2.4 percent of the firms he can claim a minority fraction of cash flow. From this perspective, there is no problem of minority shareholder exploitation.

This result is strongly influenced by the very large size of individual stakes on each level. For example, in over 45 percent of all observations control is exercised by 100 percent stakes on all levels throughout the pyramid. This mirrors a preference for strict hierarchies in large firms. To see if there is a discrepancy between cash flow and control rights we correct for the share size on the first level. ${ }^{52}$ Figure 6 shows the cash flow rights calculated as above as a percentage of the control rights on the first level of the pyramid.

\footnotetext{
${ }^{51}$ In pyramids, the importance of non-financial firms as decisive shareholders increases with the height of the pyramid.

${ }^{52}$ Share size on the first level is used as a proxy for the desired level of control (see section 2.4.1).
} 
Figure 6: Cash Flow Rights as a Percentage of Control Rights in Pyramids

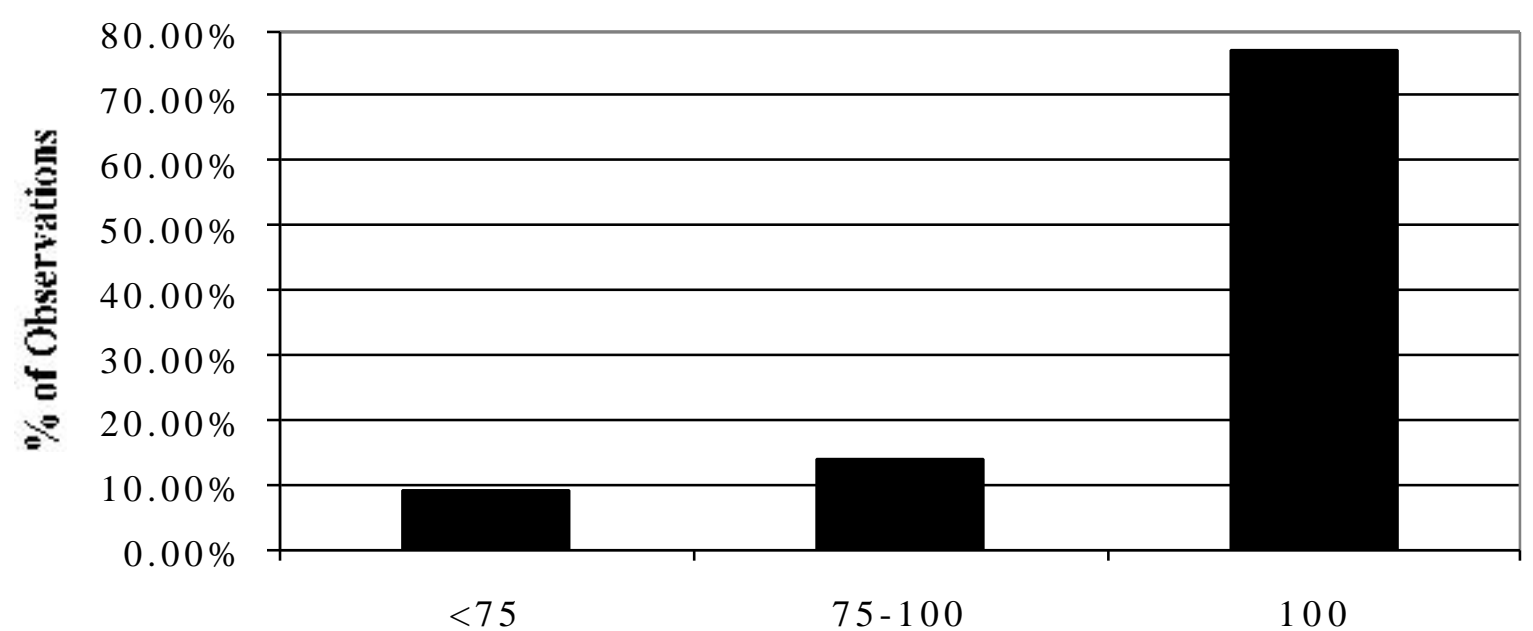

Cash Flow Rights as a Percentage of Largest Stake C1

Note: Cash flow rights are calculated as the measure suggested by BEBCHUK et al. (1998). The largest share block $\mathrm{C}_{1}$ is used as a proxy for (desired) control rights.

Figure 6 confirms that in over 76 percent of all firms cash flow rights are identical with control rights. There is no agency problem in these firms as far as they are caused by a discrepancy of cash flow and control rights. But for about a quarter of all firms Figure 6 indicates a discrepancy of cash flow and control. Only 10 percent of all firms can claim 25 percent or less of the cash flow than they should get looking at their extent of control (measured by $\mathrm{C}_{1}$ ). ${ }^{53}$ But almost 60 percent of the pyramids with no discrepancy of cash flow and control rights have non-financial institutions at their top what could hinder efficient monitoring.

\section{Cross-Ownership}

To check whether the firms in our sample are part of an insider-system we calculate their degree of cross-ownership as defined in section 2.4.2. For the year 1998 we find that out of 1519 firms only 8 are part of an insider-system as the degree of cross-ownership is larger than zero. Mostly these firms directly own their shares. This is likely to be a result of share buybacks. The degree of cross-ownership is rather small with on average 8.7 percent.

Next we check whether the ultimate shareholders of the 1519 firms in consideration are part of an insider-system because firms under the ultimate control of insider-systems are sheltered from the control of outsiders. For the year 1998 we identify 49 out of 1519 firms as being

\footnotetext{
${ }^{53}$ It must be kept in mind that only a majority of 75 percent guarantees full control over cash flow. But about 90 percent of the firms fulfill this criterion. For the other 10 percent of firms our measure is a proxy (see section 2.4.1).
} 
ultimately controlled by an insider-system. The average degree of cross-ownership is only 4.5 percent. This, however, is a result of long loops of cross-shareholdings as Figure 7 illustrates:

\section{Figure 7: Length of Loop in Cross-Shareholdings}

$$
\begin{aligned}
& \text { Length of Loop }=2 \\
& \text { Degree of Cross- Ownership }=1 \%
\end{aligned}
$$

Firm A

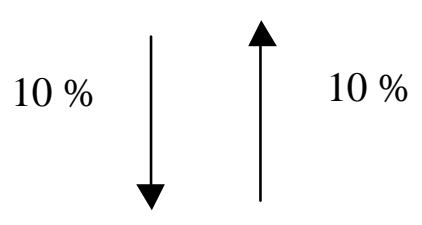

Firm B
Length of Loop $=4$

Degree of Cross- Ownership $=0.01 \%$

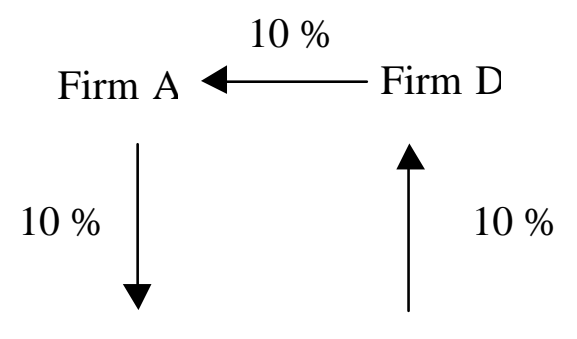

Firm B $\longrightarrow$ Firm C

$10 \%$

In the example of Figure 7 all firms hold a share of 10 percent in each other. But the degree of cross-shareholdings shrinks with the length of the loop. Therefore and because the length of the loop is an interesting characteristic of insider-systems by itself Table 12 shows the degree of cross-ownership by length of loop:

Table 12: Cross-Ownership by Length of Loop ${ }^{1}$

\begin{tabular}{rrr}
\hline Length of Loop & Number of Firms & Degree of Cross-Ownership ${ }^{2}$ \\
\hline own shares & 6 & 14.19 \\
2 & 8 & 14.98 \\
4 & 23 & 0.18 \\
6 & 1 & 0.27 \\
9 & 9 & 7.69 \\
25 & 10 & 1.05 \\
\hline Total & 57 & Weighted Average: 5.07 \\
\hline
\end{tabular}

Note: ${ }^{1}$ Length of loop is defined as the number of firms over which a firm holds shares in itself. ${ }^{2}$ Degree of cross-ownership is defined as the size of the share a firm ultimately holds in itself. It is calculated by multiplying the share sizes throughout each loop and then adding the results over all loops of a particular firm.

Table 12 broadly confirms that the degree of cross-ownership as defined in section 2.4.2 shrinks with the length of the loop. We see that six firms hold own shares directly, eight firms over one intermediate firm. In some cases the length of the loop is very long. These loops correspond to the well-known figures presented by ADAMS (1994). But in most cases the web of cross-shareholdings is small in terms of the number of firms involved.

Looking at the small number of firms which are part of an insider-system or ultimately controlled by an insider-system cross-ownership seems to be a phenomenon of minor relevance in German manufacturing firms. Only 57 (i.e. 3.75 percent) out of 1519 firms fulfill our criteria for insider-systems. We might underestimate the relevance of insider-systems, however, by 
simply counting the number of insider-controlled firms. Therefore we calculate the fraction of sales which are generated by insider-controlled firms to total sales. Here we find that the 3.75 percent of insider-controlled firms produce about 7.6 percent of the total output of the 1519 firms for which we have ownership data. The analogous figure for the balance sheet total is 7.4 percent. $^{54}$

As a result we find that cross-ownership is of minor relevance when we look at the absolute number of firms which are controlled by insider-systems. Relevance increases when we look at the size of these insider-controlled firms: They produce significantly higher output and have larger balance sheet totals than the average firm which is not controlled by an insider system. Note that our results represent only a lower bound of the relevance of crossownership in the German manufacturing sector because our definition of the ultimate shareholder is rather cautious. Shareholdings much lower than 50 percent can be sufficient to control a firm completely. ${ }^{55}$ Finally, this study focuses on the manufacturing sector. Since other sectors of the German economy, in particular the financial service industry, is known to be more concentrated and characterized by cross-shareholdings (MONOPOLKOMMISSION 1998: 193), our results might represent a lower bound also in this perspective.

What also can be learned from this section is that pyramids are a relevant phenomenon in Germany. A minority of firms is controlled through pyramids of three and more levels of ownership. A separation of cash flow and control cannot be found for the large majority of firms. As a result, agency costs are not likely to be caused by pyramids. However, if nonfinancial firms were weak monitors, this would drive agency costs especially in pyramids because non-financial firms usually are located at each level and because over 40 percent of the ultimate shareholders are non-financial firms.

\section{Conclusions}

This study documents the ownership structures of large German manufacturing firms as an important element of corporate governance. It addresses several shortcomings of the previous German empirical literature.

First, principally all types of firms in the legal form of the Kapitalgesellschaft have agency conflicts resulting from the separation of ownership and control (JENSEN and MECKLING

\footnotetext{
${ }^{54}$ We could not calculate the analogous figure for the workforce employed because we do not have sufficient employment data on all 1519 firms.

55 See section 2.4.1.
} 
1976). We therefore analyze a large sample of listed and non-listed firms with different legal forms. The results show that German shareholdings are highly concentrated in the hands of a few large shareholders. The average size of the largest share block is over 81 percent in 1998. A comparison between listed and non-listed firms shows a lower but still high share concentration for the listed Aktiengesellschaft (AG): 60 percent of the AG firms have a shareholder that holds more than 50 percent of all shares. From this perspective the potential for agency conflicts is small.

Further analysis shows that in over 60 percent of the cases the largest shareholder is another non-financial enterprise. Therefore agency conflicts might arise because the controllers are plagued by internal agency conflicts (VON THADDEN 1990). Again, this problem is the least severe for the listed AG.

The second shortcoming of previous analyses we address is the neglect of changes in the ownership structure over time. Ownership concentration is stable for most non-listed firms but only for 25 percent of listed firms. It increases in almost half of the AG firms from 19941998. In addition, the ownership structure by type exhibits significant changes. Therefore, ownership structure is not constant as commonly assumed. This is particularly true for the case of the listed AG.

Third, the analysis of higher levels of the ownership structure shows that the largest majority of firms is controlled from the first or second level. Only about 14 percent of the firms are governed through a pyramid with three or more levels. This suggests that agency costs esulting from a separation of cash flow and control (BEBCHUK et al. 1998) is probably irrelevant for most German firms. However, over 40 percent of the ultimate controllers are nonfinancial firms making agency costs in the sense of VON THADDEN (1990) likely.

Finally, cross-ownership is not wide-spread in the German manufacturing sector regarding the absolute number of insider-controlled firms. In terms of firm size insider-systems caused by cross-shareholdings are a more common but still minor phenomenon. However, in practice the influence of insider systems might be much greater because we use a rather cautious definition of ultimate shareholdings. Therefore our results represent only a lower bound for crossshareholdings in Germany. Keep also in mind that in this study we exclusively analyze the German manufacturing sector. The intense discussion of cross-shareholdings in Germany primarily focuses on the financial service sector (ADAMS 1994).

This study discovered some prospective avenues for future research. First, changes in the ownership structures should be analyzed in more detail. In this study we analyzed changes in 
the aggregate shareholder concentration and in the aggregate shareholder type. If changes in individual shareholders can be identified this will allow to analyze the market for ownership stakes. BETHEL et al. (1998) and RENNEBOOG (1996) document an active share market of friendly takeovers for the US and Belgium respectively. Especially in the light of the lack of hostile takeovers in Germany (FRANKS and MAYER 1993) this could be an important mechanism for corporate control. Second, the documented differences between listed and non-listed firms and the changes in ownership structures do not necessarily imply a bias in previous studies. For example, only when changes in the ownership structure indeed affect corporate performance after taking into account the endogeneity problem (BÖRSCH-SUPAN and KÖKE, 1999), the correctness of previous results can be assessed. But this can only be achieved by an econometric analysis including all relevant mechanisms of corporate governance. 


\section{Appendix: Characteristics of Ownership Structure}

\begin{tabular}{ll}
\hline Measure & Definition of Measure \\
\hline $\mathrm{C} 1(\mathrm{C} 2, \mathrm{C} 3)$ & Size of largest block (two/three largest blocks) \\
Herfindahl Index & Herfindahl index $\mathrm{H}=\sum_{\mathrm{i}=1}^{\mathrm{N}} \mathrm{P}_{\mathrm{i}}^{2}$ with $\mathrm{P}_{\mathrm{i}}$ being the individual share \\
Voting Power & $\begin{array}{l}\text { Dummy=1 if probability exceeds } 95 \% \text { that largest shareholder will win a } \\
\text { vote, } 0 \text { otherwise: }\end{array}$ \\
& $\alpha=\Phi\left(\frac{\mathrm{C}_{1}}{\sqrt{\left(\mathrm{H}-\mathrm{C}_{1}^{2}\right.}}\right)$ with $\mathrm{C}_{1}$ the largest share block, H the Herfindahl index,
\end{tabular}

$\Phi$ the standard normal distribution function, and the critical value $\alpha_{c}$ taken from a standard normal distribution (e.g. for $\alpha=0.05$ ). If $\alpha \geq \alpha_{c}$ the dummy will be 1 .

Type

1 Dispersed Shares

2 Individuals (Families, Partnerships, Managers)

3 Non-financial enterprises

4 State

5 Banks, insurance companies, mutual and investment funds

6 Foreigners (financial and non-financial firms, state)

Level of Ult imate Control

Ultimate Owner

Pyramid: Cash

Flow Rights

Pyramid: Discrepancy of Cash Flow and Control

Insider System

Cross-ownership of the pyramid

Shareholder who has full control over a firm (either directly through a share of over $50 \%$ or indirectly through a pyramid with over $50 \%$ majority control at each level) and itself is not controlled by any majority shareholder

Cash flow rights of the ultimate shareholder in a pyramid: $\alpha=\prod_{i=1}^{N} p_{i}^{2}$ where $\mathrm{p}_{\mathrm{i}}>50 \%$ share $\left(C_{1}\right)$ in the firm at the bottom of the pyramid: $\beta=\frac{C_{1}}{\alpha}$ where $\alpha$ is the cash flow rights of the ultimate owner

A firm is part of an insider system when it directly or indirectly owns some fraction of its own shares. A firm is controlled by an insider system when its ultimate shareholder is an insider system

Size of share stake which a firm owns in itself - either directly or indirectly:
Theoretical Foundation

SHLEIFER and VISHNY (1986)

DEMSETZ and LEHN (1985)

CUBBIN and LEECH (1983)

BLACK (1992), JENSEN and MECKLING (1976), POUND (1988), SHAPIRO and WILLIG (1990), STULZ (1988), VON THADDEN (1990)

author's definition

BEBCHUK et al. (1998), GROSSMAN and HART (1988), HARRIS and RAVIV (1988)

author's definition

author's definition $\alpha=\sum_{j=1}^{J} \prod_{i=1}^{N} p_{i}^{2}$ with $p_{i}>1 \%, N$ the length of each ownership loop, and $J$ the number of these loops. 


\section{References}

Adams, M. (1994), Die Usurpation von Aktionärsbefugnissen mittels Ringverflechtung in der "Deutschland AG", Die Aktiengesellschaft 4, 148-158.

Baums, T. and C. Fraune (1995), Institutionelle Anleger und Publikumsaktiengesellschaft: eine empirische Untersuchung, Die Aktiengesellschaft 40, 97-112.

Bebchuk, L., R. Kraakman and G. Triantis (1998), Stock Pyramids, Cross-Ownership, and Dual Class Equity: The Creation and Agency Costs of Separating Control From Cash Flow Rights, NBER Working Paper No. 6951.

Becht, M. (1997), Beneficial Ownership of Listed Companies in the United States, Working Paper, Universite Libre de Bruxelles.

Becht, M. and E. Böhmer (1999), Transparency of Ownership and Control in Germany, Working Paper, Universite Libre de Bruxelles.

Berle, A. A. and G. C. Means (1932), The Modern Corporation and Private Property, New York.

Bethel, J. E., J. Porter Liebeskind und T. Opler (1998), Block Share Purchases and Corporate Performance, Journal of Finance 53 (2), 605-634.

Beyer, J. (1998), Managerherrschaft in Deutschland, Opladen.

Bianchi, M., M. Bianco and L. Enriques (1997), Ownership, Pyramidal Groups, and Separation Between Ownership and Control in Italy, Working Paper, Consob.

Black, B. S. (1992), Institutional Investors and Corporate Governance: The Case for Institutional Voice, Journal of Applied Corporate Finance, 19-32.

Black, B. S. (1997), Shareholder Activism and Corporate Governance in the United States, Working Paper, Columbia University.

Blair, M. (1995), Ownership and Control: Rethinking Corporate Governance for the TwentyFirst Century, Washington DC.

Blommestein, H. (1998), The New Financial Landscape and Its Impact on Corporate Governance, in: Balling, M., E. Hennessy and R. O'Brien (eds.), Corporate Governance, Financial Markets and Global Convergence, Dordrecht/NL.

Böhmer, E. (1998), Ownership Structure and Firm Performance in Germany: Institutional Background and Empirical Evidence, Working Paper, Humboldt University Berlin.

Börsch-Supan, A. and J. Köke (1999), Corporate Governance and the Identification Problem: Lessons from Empirical Studies, ZEW Discussion Paper, forthcoming.

Bolton, P. and E.-L. von Thadden (1996), The Ownership Structure of Firms: Liquidity and Control in the Privately Held Firm, The Decision to Go Public, 15-40.

Cable, J. (1985), Capital Market Information and Industrial Performance: The Role of West German Banks, Economic Journal 95, 118-132.

Carleton, W. T., J. M. Nelson and M. S. Weisbach (1998), The Influence of Institutions on Corporate Governance through Private Negotiations: Evidence from TIAA-CREF, Journal of Finance 53 (4), 1335-1362.

Crespi, R. (1997), A Survey on Spanish Corporate Governance Rules, Statistics and Institutions, Working Paper, Universitat Autonoma de Barcelona. 
Cubbin, J. and D. Leech (1983), The Effect of Shareholder Dispersion on the Degree of Control in British Companies: Theory and Measurement, Economic Journal 93, 351-369.

De Jong, A., R. Kabit and A. Röell (1997), Ownership and Control in the Netherlands, Working Paper, Tilburg University and Universite Libre de Bruxelles.

Del Guercio, D. and J. Hawkins (1999), The Motivation and Impact of Pension Fund Activism, Journal of Financial Economics 52, 293-340.

Demsetz, H. and K. Lehn (1985), The Structure of Corporate Ownership: Causes and Consequences, Journal of Political Economy 93 (6), 1155-1177.

Denis, D. J. and A. Sarin (1999), Ownership and Board Structures in Publicly Traded Corporations, Journal of Financial Economics 52 (2), 187-224.

ECGN (1997), The Separation of Ownership and Control: A Survey of 7 European Countries, Preliminary Report to the European Commission, http://www.ecgn.ulb.ac.be/ecgn/euprelimreport.htm.

Edwards, J. and K. Fischer (1994), Banks, Finance and Investment in Germany, Cambridge.

Feuerstack, R. (1999), Konzentrationsmessung im Handel, in: Michael F. und A. Kaapke (Hrsg.), Fallstudienbuch zur Handelsbetriebslehre.

Franks, J. and C. Mayer (1993), The Market for Corporate Control in Germany, Working Paper, London Business School und University of Warwick.

Franks,J. and C. Mayer (1994), The Ownership and Control of German Corporations, Working Paper, London Business School und University of Oxford..

Franks, J. and C. Mayer (1995), Ownership and Control, in: Siebert, H. (ed.), Trends in Business Organization, 171-200.

Gerke, W. et al. (1995), Probleme deutscher mittelständischer Unternehmen beim Zugang zum Kapitalmarkt: Analyse und wirtschaftspolitische Schlußfolgerungen, BadenBaden.

Gorton, G. and F. A. Schmid (1996), Universal Banking and the Performance of German Firms, Working Paper, University of Pennsylvania.

Grossman, S. J. and O. D. Hart (1980), Takeover Bids, the Free-Rider Problem, and the Theory of the Corporation, Bell Journal of Economics 11, 42-64.

Grossman, S. J. and O. D. Hart (1988), One Share-One Vote and the Market for Corporate Control, Journal of Financial Economics 20, 175-202.

Harris, M. and A. Raviv (1988), Corporate Governance: Voting Rights and Majority Rules, Journal of Financial Economics 20, 203-235.

Himmelberg, C. P., G. R. Hubbard and D. Palia (1999), Understanding the Determinants of Managerial Ownership and the Link between Ownership and Performance, Journal of Financial Economics 53 (3), 353-384.

Hopt, K. (1998), The German Two-Tier Board (Aufsichtsrat): A German View on Corporate Governance, in: Hopt, K. and E. Wymeersch (eds.), Comparative Corporate Governance: Essays and Materials, Berlin, 3-20.

Jensen, M. C. and W. H. Meckling (1976), Theory of the Firm: Managerial Behavior, Agency Costs, and Ownership Structure, Journal of Financial Economics 3, 305-360.

Kammerath, J. (1999), Methodische und empirische Grundlagen der quantitativen Erfassung kontrollierender Verbindungen deutscher Unternehmen mit ihren direkten und 
indirekten Eignern, Gutachten im Auftrag des ifo Institut für Wirtschaftsforschung, München, unpublished manuscript.

Karpoff, J.M. (1998), The Impact of Shareholder Activism on Target Companies: A Survey of Empirical Findings, Working Paper, University of Washington.

Köke, J. (1999), Firmendatenbank zum Projekt "Corporate Governance in Deutschland": Datenquellen, Aufbau und Inhalt, ZEW Documentation, forthcoming.

La Porta, R., F. Lopez-de-Silanes and A. Shleifer (1999), Corporate Ownership Around the World, Journal of Finance 54 (2), 471-517.

Leech, D. and J. Leahy (1991), Ownership Structure, Control Type Classifications and the Performance of Large British Companies, Economic Journal 101, 1418-1437.

Monopolkommission (1998), Hauptgutachten 1996/1997, Baden-Baden.

Morck, R., A. Shleifer and R. W. Vishny (1988), Management Ownership and Market Valuation, Journal of Financial Economics 20, 292-315.

Myers, Stewart (1977), Determinants of Corporate Borrowing, Journal of Financial Economics 5, 147-175.

Nibler, M. (1995), Bank Control and Corporate Performance in Germany: The Evidence, Working Paper, University of Cambridge.

Pfannschmidt, A. (1993), Personelle Verflechtungen über Aufsichtsräte: Mehrfachmandate in deutschen Unternehmen, Wiesbaden.

Porter, M. E. (1992), Capital Disadvantage: America's Failing Capital Investment System, Harvard Business Review 70 (5), 65-82.

Pound, J. (1988), Proxy Contests and the Efficiency of Shareholder Oversight, Journal of Financial Economics 20, 237-265.

Prowse, S. (1994), Corporate Governance in an International Perspective: A Survey of Corporate Governance Mechanisms Among Large Firms in the United States, the United Kingdom, Japan, and Germany, Bank for International Settlements Paper 41, 6-79.

Renneboog, L. (1996), Shareholding Concentration and Pyramidal Ownership Structures in Belgium: Stylized Facts, Working Paper 9635, Catholic University of Leuven.

Seger, F. (1997), Banken, Erfolg und Finanzierung: Eine Analyse für Deutsche Industrieunternehmen, Wiesbaden.

Shapiro, C. and R. D. Willig (1990), Economic Rationales for the Scope of Privatization, in: Suleiman, E.N. and J. Waterbury (eds.), Political Economy of Public Sector Reform and Privatization, London, 55-87.

Shleifer, A. and R. W. Vishny (1986), Large Shareholders and Corporate Control, Journal of Political Economy 94 (3), 461-488.

Shleifer, A. and R. W. Vishny (1997), A Survey of Corporate Governance, Journal of Finance, 52 (2), 737-783.

Short, H. (1994), Ownership, Control, Financial Structure and the Performance of Firms, Journal of Economic Surveys 8 (3), 203-247.

Smith, M. P. (1996), Shareholder Activism by Institutional Investors: Evidence from CalPERS, Journal of Finance 51 (1), 227-252.

Statistisches Bundesamt (1999), Umsatzsteuerstatistik, Table VIIb, Wiesbaden. 
Steiner, M. (1998), Konstitutive Entscheidungen, in: Bitz, M. et al. (Hrsg.), Vahlens Kompendium der Betriebswirtschaftslehre, München, 57-106.

Stulz, R. M. (1988), Managerial Control of Voting Rights, Journal of Financial Economics 20, 25-54.

von Thadden, E.-L. (1990), On the Efficiency of the Market for Corporate Control, Kyklos 43, 635-658.

Wenger, E. and C. Kaserer (1997), The German System of Corporate Governance - A Model which Should Not Be Imitated, Working Paper, The John Hopkins University. 